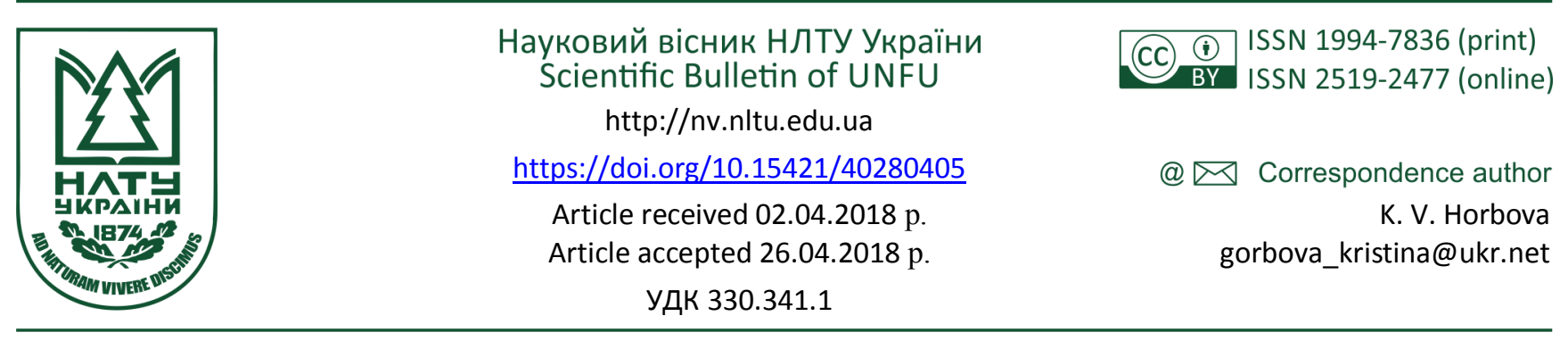

Х. П. Данилків, Х. В. Горбова, О. Я. Побурко

Національний університет "Львівська політехніка", м. Львів, Україна

\title{
ІННОВАЦІЙНИЙ РОЗВИТОК ТРАНСПОРТНОЇ СИСТЕМИ УКРАЇНИ
}

Дослідження складових транспортного комплексу (залізничний транспорт, автомобільний, водний) дало змогу стверджувати, що транспортна система є важливим сегментом для економіки країни, стабільне функціонування якого забезпечує необхідні умови цілісності держави та підвищення рівня життя населення. Проаналізовано стан транспортної системи України та розглянуто перспективи ії розвитку в контексті кризових змін. Визначено негативні тенденції у перевезеннях. Відзначено зменшення вантажообігу залізничного, автомобільного, водного, трубопровідного й авіаційного транспорту. Ринок транспортних послуг задовольняє тільки базові потреби економіки України та населення у перевезеннях. Виявлено, що нерозвинена система управління транспортною системою, стан виробничо-технічної бази і технологічний рівень організації перевезень за багатьма параметрами не відповідають зростаючим потребам суспільства, що негативно впливає на транспортну систему країни. Перспективним для держави визначено інноваційні перетворення в напрямку удосконалення структури міжнародних транспортно-логістичних систем, запровадження інноваційних інформаційно-управлінських технологій, побудованих на моделюванні інтегрованих транспортних систем, розвиток мультимодальних перевезень та пришвидшене інтегрування національної транспортної системи.

Ключові слова: інновації; транспортно-дорожній комплекс; перевезення; сталий розвиток; інфраструктура; державна політика.

Вступ. В умовах динамічного розвитку сучасного суспільства, глобалізації світової економіки, активізація зовнішньоекономічних торговельних відносин, популяризація туризму серед населення в усьому світі зумовлюють визначальну роль та місце інновацій у забезпеченні конкурентоспроможності національної транспортної системи України та створенні реальних можливостей іiі інтеграції до європейської та світової транспортних систем.

Головне завдання держави у сфері функціонування та інноваційного розвитку транспорту полягає у створенні умов для економічного зростання, підвищення конкурентоспроможності національної економіки та якості життя населення через забезпечення доступу до безпечних і сучасних транспортних послуг, перетворення географічних особливостей країни на їі конкурентні переваги. Стратегічною метою розвитку транспортної системи $є$ задоволення потреб інноваційного розвитку економіки і суспільства в конкурентоспроможних транспортних послугах (Karmazina, 2015; Pashchenko \& Nykyforuk, 2008).

Досягнення цієї стратегічної мети може бути забезпечено завдяки ефективному розвитку конкурентного середовища у транспортній галузі, досягненню передового рівня розвитку техніки і технологій, посиленню

уваги до соціальних і екологічних факторів (Komitet, n.d.; Sobkevych, Mykhailychenko \& Yemelianova, n.d.).

Для цього передусім потрібно визначити ті ключові пріоритетні напрями розвитку транспортної системи, за якими країна зможе отримати додаткові економічні та соціальні вигоди, раціонально використовуючи свої фінансові ресурси (Preiher, Sobakevych \& Yemelianova, 2011; Stratehiia, n.d.).

Обговорення отриманих результатів. Упродовж останніх років транспортна система України переживає період нестабільності. Стан виробничо-технічної бази і технологічний рівень організації перевезень за багатьма параметрами не відповідають зростаючим потребам суспільства та європейським стандартам якості надання транспортних послуг. Водночас скорочення обсягів перевезень пов'язане із критичним станом інфраструктури та рухомого складу залізничного транспорту, що заважає доставляти вантажі швидко, вчасно та без втрат. Хоча у 2011 р. і відбулося поступове відновлення обсягів вантажних і пасажирських перевезень, проте наступна соціально-економічна криза та воєнні дії у країні знову призвели до негативної динаміки й у 2016 р. значення цих показників стали рекордно низькими (табл. 1 та 2).

\section{Інформація про авторів:}

Данилків Христина Петрівна, канд. екон. наук, асистент, кафедра фінансів, обліку і аналізу. Email: krisdanko@ukr.net; https://orcid.org/0000-0003-1283-6844

Горбова Христина Володимирівна, канд. екон. наук, доцент, кафедра фінансів, обліку і аналізу. Email: gorbova_kristina@ukr.net; https://orcid.org/0000-0001-7826-5728

Побурко Олексій Ярославович, канд. екон. наук, доцент, кафедра фінансів. Email: opoburko@gmail.com

Цитування за ДСТУ: Данилків Х. П., Горбова Х. В., Побурко О. Я. Інноваційний розвиток транспортної системи України. Науковий вісник НЛТУ України. Серія Економічна. 2018, т. 28, № 4. С. 31-35

Citation APA: Danylkiv, K. P., Horbova, K. V., \& Poburko, O. Ya. (2018). Innovative Development of the Transport System of Ukraine. Scientific Bulletin of UNFU, 28(4), 31-35. https://doi.org/10.15421/40280405 
Табл. 1. Динаміка перевезень вантажів у 2000-2016 рр. (млн т)

\begin{tabular}{|c|c|c|c|c|c|c|c|c|c|}
\hline Роки & 2000 & 2005 & 2010 & 2011 & 2012 & 2013 & 2014 & 2015 & 2016 \\
\hline Транспорт & 1529 & 1805 & 1765 & 1887 & 1853 & 1837 & 1623 & 1474 & 1543 \\
\hline залізничний ${ }^{1}$ & 357 & 450 & 433 & 469 & 457 & 444 & 386 & 350 & 343 \\
\hline морський & 6,3 & 8 & 4 & 4 & 4 & 3 & 3 & 3 & 3 \\
\hline річковий & 8,3 & 13 & 7 & 6 & 4 & 3 & 3 & 3 & 4 \\
\hline автомобільний - усього ${ }^{2}$ & 939 & 1121 & 1168 & 1253 & 1260 & 1261 & 1131 & 1021 & 1086 \\
\hline зокрема, автопідприємства & 99 & 106 & 99 & 118 & 122 & 126 & 131 & 109 & 123 \\
\hline авіаційний $^{3}$ & 0,0 & 0,1 & 0,1 & 0,1 & 0,1 & 0,1 & 0,1 & 0,1 & 0,1 \\
\hline трубопровідний & 218 & 213 & 153 & 155 & 128 & 126 & 100 & 97 & 107 \\
\hline
\end{tabular}

за даними Публічного акціонерного товариства "Українська залізниця" (далі - ПАТ "Укрзалізниця").

${ }^{2}$ з урахуванням перевезень, виконаних для власних потреб. 32005 р. - 3 урахуванням комерційних вантажних перевезень, виконаних фізичними особами-підприємцями.

3 з 2003 р. - за даними Державної авіаційної служби України.

Табл. 2. Відправлення (перевезення) пасажирів за видами транспорту (млн пас.)

\begin{tabular}{|c|c|c|c|c|c|c|c|c|c|}
\hline Роки & 2000 & 2005 & 2010 & 2011 & 2012 & 2013 & 2014 & 2015 & 2016 \\
\hline Транспорт & 7780 & 8200 & 6845 & 6980 & 6813 & 6623 & 5902 & 5167 & 4854 \\
\hline залізничний $^{1}$ & 499 & 445 & 427 & 430 & 429 & 425 & 389 & 390 & 389 \\
\hline морський & 4 & 11 & 7 & 7 & 6 & 7 & 0 & 0 & 0 \\
\hline річковий $^{2}$ & 2 & 2 & 1 & 1 & 1 & 0 & 1 & 1 & 1 \\
\hline авіційний $^{2}$ & 1 & 4 & 6 & 8 & 8 & 8 & 6 & 6 & 8 \\
\hline автомобільний (автобуси) $^{3}$ & 2557 & 3837 & 3726 & 3612 & 3450 & 3344 & 2913 & 2250 & 2025 \\
\hline тролейбусний & 2582 & 1903 & 1204 & 1346 & 1345 & 1306 & 1097 & 1081 & 1039 \\
\hline трамвайний & 1381 & 1111 & 714 & 798 & 800 & 757 & 770 & 739 & 694 \\
\hline метрополітенівський & 754 & 887 & 760 & 778 & 774 & 775 & 726 & 700 & 698 \\
\hline
\end{tabular}

1 за даними ПАТ "Укрзалізниця", з 2010 р. - з урахуванням перевезень пасажирів міською електричкою.

2 з 2003 р. - за даними Державної авіаційної служби України.

3 з урахуванням обсягів автомобільних пасажирських перевезень (автобусами), виконаних фізичними та юридичними суб'єктами малого бізнесу.

Обсяги перевезення вантажів 2016 р. досягли 1543 млн т, що становить 93,9\% від рівня 2011 р. Різке зниження показників транспортних підприємств відбулося під впливом кризової ситуації у країні (Zbirnyk, 2015). Кризові явища значною мірою позначилися на розвитку бізнесу як у транспортній галузі, так і в інших сферах економіки. Найбільша частка у структурі перевезень вантажів, як і раніше належить автомобільному транспорту - 70,38\%. Друге і третє місце посідають залізничний і трубопровідний транспорт - 22,26 \% та $6,92 \%$ відповідно. У 2016 р. питома вага морського транспорту в перевезенні вантажів становила $0,20 \%$, річкового $0,24 \%$, авіаційного $-0,005 \%$ (рис. 1 ).

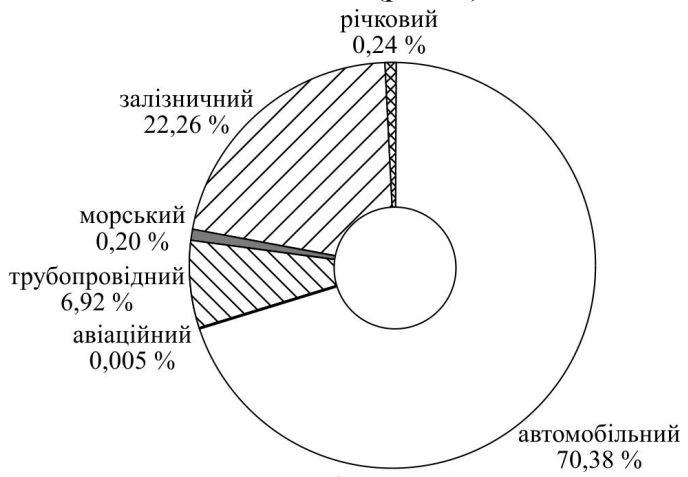

Рис. 1. Питома вага деяких видів транспорту в перевезенні вантажів у 2016 p.

Для пасажирських перевезень також властива негативна динаміка (табл. 2). Обсяг перевезень пасажирів у 2014 р., порівняно з 2011 р., становив 90,6 \%. Насамперед це можна пов'язати з істотним відставанням росту доходів населення від росту споживчих цін та скороченням диференціації рівня добробуту населення України.Найбільша частка у структурі перевезень пасажирів, як і раніше, належить автомобільному (автобуси) транспорту $-41,72 \%$. Друге місце посідає тролейбусний транспорт - $21,4 \%$; третє і четверте місце - метро- політенівський i трамвайний транспорт - 14,39 та 14,3 \% відповідно (рис. 2).

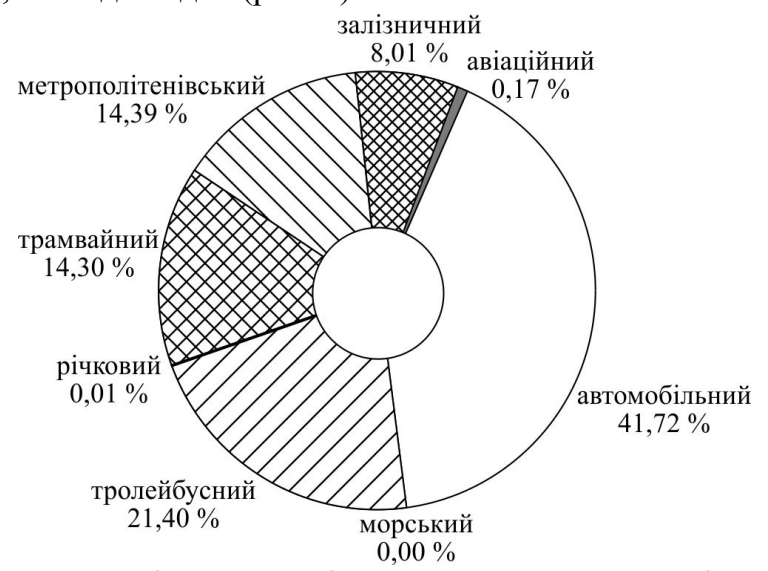

Рис. 2. Розподіл деяких видів транспорту у загальному відправленні (перевезенні) пасажирів у 2016 р.

Також скоротилося укладання договорів між українськими перевізниками й іноземними партнерами щодо надання послуг на міжнародні перевезення (табл. 3).

Табл. 3. Зовнішньоекономічні вантажопотоки через кордони України (тис. т)

\begin{tabular}{|c|c|c|c|c|c|}
\hline \multirow{2}{*}{ Показник } & \multicolumn{5}{|c|}{ Рік } \\
\cline { 2 - 6 } & 2010 & 2011 & 2012 & 2013 & 2014 \\
\hline Експорт & 142978 & 155598 & 170855 & 175558 & 174544 \\
\hline Імпорт & 78364 & 95706 & 82306 & 76134 & 60073 \\
\hline Транзит & 152354 & 151243 & 124894 & 120127 & 101993 \\
\hline Усього & 373696 & 402547 & 378055 & 371819 & 336610 \\
\hline
\end{tabular}

Через територію України пролягають потужні трансконтинентальні трубопровідні магістралі: газопроводи "Союз" (Урал - країни Європи) та "Уренгой - Ужгород" (Західний Сибір - країни Європи), а також нафтопровід "Дружба" (Західний Сибір - країни Європи). У світі Україна посідає 4 місце (після США, Росії, Канади) за показником експлуатаційної довжини залізничних колій загального користування. Залізнична мережа України в 
Європі є однією з найпотужніших, ще в 1990-х роках вона за вантажонапруженістю посідала перше місце. Україна володіє також розвиненою інфраструктурою залізничного та водного транспорту. Через Україну проходять Міжнародні транспортні коридори, зокрема: Пан'європейські транспортні коридори $(3,5,7,9)$, коридори Організації співробітництва залізниць $(3,4,5,7,8$, 10) та транспортний коридор Свропа-Кавказ-Азія (Трасека). За 2014 р. через територію України пройшло 101993,37 тис. т транзитних вантажів, 3-поміж яких найбільший обсяг припадає на трубопровідний $(64,51 \%)$, залізничний $(28,82 \%)$ та автомобільний (5,75 \%) транспорт (Stratehiia, n.d.; Yepifanova, 2012).

Рівень розвитку транспортної галузі держави - одна з вагомих ознак іiї технологічного прогресу. На сьогодні в залишаються невирішеними проблеми транспортної галузі, що характеризуються:

- спадом попиту на вантажні та пасажирські перевезення, багаторазовим зростанням цін на матеріальні ресурси, що призводить до значного зниження реальних доходів транспорту; низькою конкурентоспроможністю транспортнодорожнього комплексу на зовнішньому і внутрішньому ринках; невирішеністю питань щодо джерел фінансування;

- відсутністю іноземних та вітчизняних інвестицій у фінансуванні техніко-технологічної модернізації розвитку транспорту;

- недостатньою ефективністю функціонування транспортнодорожнього комплексу, яка пов'язана насамперед із повільним вирішенням питань приведення у відповідність 3 обсягами виконуваної роботи експлуатаційного персоналу та основних фондів, транспортної інфраструктури, а також 3 утриманням непрофільних для галузі об'єктів, низькими темпами впровадження ресурсоощадних технологій;

- недосконалістю нормативно-правового забезпечення діяльності транспортно-дорожнього комплексу, повільним вирішенням питань уніфікації транспортного законодавства відповідно до міжнародного права.

Визначальним фактором, що здатний вивести транспорту галузь із кризи на техніко-технологічний рівень розвинених країн, $є$ інноваційний розвиток та активне впровадження інноваційних процесів. Процес і термін інноваційного відродження транспортної галузі перебувають залежно від обсягів фінансової підтримки інновацій. Потреба пришвидшеного техніко-технологічного розвитку зумовлює перехід на модель інноваційно-інвестиційного розвитку, у якій розроблення та впровадження інновацій стимульовано достатнім інвестиційним забезпеченням (Preiher, Sobakevych \& Yemelianova, 2011; Zbirnyk, 2015).

За даними Держстату України кількість підприємств та організацій України, що займалися інноваційною діяльністю, у 2016 р. становила 1609 підприємств або 16,1 \% від усіх обстежених підприємств. У 2013 р. цей показник становив $16,8 \%$. В інноваційно розвинених країнах цей показник в 3-4 рази вищий. Серед регіонів найбільша частка інноваційно активних підприємств припадає на економічно та промислово розвинені регіони: м. Київ (21,7\%), Херсонську (24,2 \%), Запорізьку $(22,9 \%), \quad$ Івано-Франківську $(22,8 \%), \quad$ Харківську $(22,4 \%)$ та Миколаївську (19,9\%) області.

Інноваційну діяльність щороку припиняють сотні підприємств. Чинниками, які насамперед перешкоджали здійсненню інноваційної діяльності, були вартісні, а саме: нестача власних коштів, великі витрати на нововведення, недостатня фінансова підтримка держави, ви- сокий економічний ризик, тривалий термін окупності нововведень. Також заважала недосконалість законодавчої бази, відсутність попиту на продукцію та кваліфікованого персоналу.

Варто зазначити, що у 2016 р. 203 транспортні підприємства використовували у своїй діяльності передові технології. Загальна кількість таких технологій становила 754 одиниці, це 4,3 \% від загальної кількості використаних в аналізованому періоді передових технологій. Із загальної кількості використовуваних технологій 43,6 \% були новими (іхній термін упровадження становив до 3 років включно), майже кожна четверта технологія використовувалася 10 років і більше. Кожна друга технологія групи "Автоматизоване транспортування матеріалів і деталей, здійснення автоматизованих вантажно-розвантажувальних операцій" була новою.

У звітному році підприємства транспорту, окрім передових технологій, у своїй діяльності використовували 31 винахід та 13 корисних моделей. Майже половину $(43,6 \%)$ з усіх раціоналізаторських пропозицій було впроваджено на підприємствах транспорту та зв'язку. Їх впроваджували 19 підприємств галузі.

Важливим фактором, який визначає стан інноваційної діяльності у країні, є іiї фінансування. Фінансування інноваційної діяльності є складовим елементом фінансової політики держави. Вона має забезпечити створення необхідних передумов для збереження i розвитку науково-технічного потенціалу країни, швидкого й ефективного впровадження новинок в усі галузі економіки, забезпечення його структурно-інноваційної перебудови. У багатьох країнах держава бере на себе від 20 до 50 \% національних наукових витрат. Для фундаментальних досліджень зазначений показник набагато вищий (від половини до 2/3). У 2014 р. загальний обсяг витрат на виконання наукових і науково-технічних робіт власними силами організацій становив 10320,3 млн грн, зокрема, 143550,6 тис. грн у сфері транспорту і зв'язку.

Основним джерелом фінансування інноваційних витрат підприємств транспорту залишаються власні кошти підприємств, кошти державного бюджету України та підприємств-замовників інноваційних розробок. Зважаючи на те, що джерелом власних коштів підприємств, що спрямовуються на інноваційну діяльність, є прибуток, стає зрозумілою причина низького рівня інноваційної активності. Більшість підприємств працює збитково, а ті, що отримують прибуток, не поспішають ним ризикувати, адже інноваціям притаманний високий рівень ризику. Саме тому для розвитку інноваційної діяльності доцільно активно розвивати банківський сектор у частині залучення цільових інвестицій, вигідного вкладення вільних фінансових коштів підприємств, фінансування перспективних науковотехнічних досягнень.

Проведений аналіз показав, що на сьогодні інноваційна діяльність підприємств транспорту характеризується негативною динамікою. Показники динаміки роботи транспортної галузі свідчать про загострення проблем, що нагромаджувались у ній упродовж останніх 26 років, які не дають змогу швидко і з мінімальними втратами вийти із кризового стану. Сьогодні ринок транспортних послуг задовольняє тільки базові потреби економіки України та населення у перевезеннях. 
Головною причиною такого стану ТДК України стало порушення положень економічних законів, які регулюють процеси простого та розширеного відтворення основних виробничих фондів. Як наслідок, створений ще за радянських часів запас технічних ресурсів галузі (інфраструктури, рухомого складу) практично вичерпано й виникла реальна загроза втрати іiі стійкості. Транспорт, що $\epsilon$ однією 3 найбільш фондомістких галузей господарства, потребує для свого розвитку великих довготермінових інвестицій, і для забезпечення його сталої подальшої роботи необхідно залучити в галузь значні кошти. Проте можливості держави тут обмежені, а власні ресурси підприємств вичерпані. Застосування механізмів державно-приватного партнерства не набуло поширення внаслідок відсутності в Україні достатньої нормативно-правової бази для реалізації механізмів ДПП та належних гарантій прав інвесторів.

Другою системною причиною кризового стану транспортної галузі $\epsilon$ те, що ринкові механізми наразі не стали основним іiі регулятором. Слаборозвиненими $\epsilon$ механізми конкуренції та самоорганізації транспортних підприємств, а державне регулювання ринку транспортних послуг $\epsilon$ недостатньо ефективним. Зберігається монополія у потенційно-конкурентних сегментах перевезень на залізничному транспорті, а наявна неефективна система управління державними транспортними підприємствами призводить до незадовільних результатів їхньої роботи, збитковості, неспроможності забезпечити оновлення власного рухомого складу та відтворення застарілої транспортної інфраструктури на паритетних 3 державою та приватними інвесторами засадах.

По-третє, світові тенденції розвитку товарних ринків, підвищення мобільності населення, глобалізаційні процеси та євроінтеграційні умови висувають нові вимоги до функціонування транспортних систем і ринків, проте державна політика щодо розвитку транспортної галузі не відповідає цим викликам.

Транспортна стратегія України на період до 2020 р. так і не набула розвитку в конкретних програмних документах, тобто на сьогодні не існує затверджених програм розвитку транспортних галузей на середньотермінову перспективу (за винятком Державної цільової економічної програми розвитку автомобільних доріг загального користування на 2013-2018 рр.). Відповідно розвиток залізничного, водного, авіаційного, автомобільного транспорту та дорожнього господарства України відбувається значною мірою за інерцією і не спрямований на досягнення конкретних і обгрунтованих цілей. Структурні реформи у транспортному секторі відбуваються вкрай повільно, а в окремих транспортних підгалузях були фактично заблоковані протягом тривалого періоду часу. "Консервування" структурних реформ у монопольних сегментах ТДК, насамперед на залізничному транспорті, унеможливило своєчасне проведення розмежування функцій державного і господарського управління, загальмувало процеси формування прогресивної виробничо-технологічної системи залізничного транспорту, структурованої за видами діяльності, досі не дає змогу демонополізувати перевізний процес та забезпечити доступ до ринку перевезень приватних компаній.

На державному рівні наразі не сформульовано стратегічне бачення конкурентних переваг ТДК України порівняно з іншими країнами, перспектив розвитку транзитних вантажопотоків 3 урахуванням світової кон'юн- ктури ринку і глобальної виробничої спеціалізації країн, що знижує можливості інтеграції України до світової транспортної системи й участі в обслуговуванні транснаціональних вантажо- і пасажиропотоків.

Висновки. Враховуючи зазначене вище, транспортний сектор перетворюється для держави на чинник ризику, що не піддається точним прогнозам. У разі зволікання із запровадженням ефективних заходів державної політики ймовірна неспроможність транспортної галузі забезпечити в найближчій перспективі потреби економічного зростання країни у перевезеннях, а також потреби населення у пересуванні через подальше зростання платоспроможного попиту, розвиток бізнесу та туризму. Існують ризики повної втрати конкурентоспроможності національної транспортної системи України, які виявлять себе у неспроможності країни брати участь в обслуговуванні основних транснаціональних і трансконтинентальних вантажопотоків між Заходом і Сходом та остаточній втраті транзитного потенціалу.

Для покращення ситуації, що склалася у транспортній галузі, пришвидшення іiї виходу з кризи та надання необхідного імпульсу для подальшого розвитку, потрібно розробити і здійснити низку економічних, структурних, організаційних, технологічних та інституційних перетворень на транспорті. Напрями державної політики мають виходити із завдань євроінтеграції, передбачати всебічну підготовку української транспортної системи до імплементації Угоди про асоціацію з ЄС. При цьому пріоритетами мають стати формування в Україні ефективного конкурентоспроможного ринку транспортних послуг та побудова збалансованої за видами транспорту національної транспортної системи, здатної задовольнити в повному обсязі потреби економіки та населення у перевезеннях, забезпечити належну якість і безпеку перевізного процесу, зменшити негативний вплив транспорту на довкілля, а також повною мірою реалізувати транзитний потенціал України.

\section{Перелік використаних джерел}

Karmazina, O. O. (Ed.). (2015). Transport i zviazok Ukrainy 2014: statystychnyi zbirnyk. Kyiv: Derzhavna sluzhba statystyky Ukrainy, 204 p. [In Ukrainian].

Komitet. (n.d.). Derzhavnyi komitet statystyky [ofitsiinyi sait]. Retrieved from: www.ukrstat.gov.ua. [In Ukrainian].

Pashchenko, Yu. Ye., \& Nykyforuk, O. I. (2008). Transportno-dorozhnii kompleks Ukrainy $v$ protsesakh mizhnarodnoi intehratsii. Nizhyn: Aspekt-Polihraf. 192 p. [In Ukrainian].

Preiher, D. K., Sobakevych, O. V., \& Yemelianova, O. Yu. (2011). Realizatsiia potentsialu transportnoi infrastruktury Ukrainy $v$ stratehii postkryzovoho ekonomichnoho rozvytku. Kyiv: NISD. 37 p. [In Ukrainian].

Sobkevych, O. V., Mykhailychenko, K. M., \& Yemelianova, O. Yu. (n.d.). Innovatsiini peretvorennia na transporti yak chynnyk modernizatsii transportno-dorozhnoho kompleksu Ukrainy. Retrieved from: http://www.niss.gov.ua/articles/1303/\#_ftnref3. [In Ukrainian].

Stratehiia. (n.d.). Transportna stratehiia Ukrainy na period do 2020 roku. Retrieved from: http://www.mtu.gov.ua. [In Ukrainian].

Yepifanova, I. Yu. (2012). Analiz finansovoho zabezpechennia innovatsiinoi diialnosti vitchyznianykh pidpryiemstv u suchasnykh umovakh. Visnyk natsionalnoho universytetu "Lvivska politekhni$k a^{\prime \prime}$. Seriia: Menedzhment ta pidpryiemnytstvo v Ukraini: etapy stanovlennia i problemy rozvytku, 722, 65-70. [In Ukrainian].

Zbirnyk. (2015). Statystychnyi zbirnyk "Naukova ta innovatsiina diialnist $v$ Ukraini u 2014 rotsi". Kyiv: Derzhavna sluzhba statystyky Ukrainy. 255 p. [In Ukrainian]. 
К. П. Данылкив, К. В. Горбова, А. Я. Побурко

Национальный университет "Львовская политехника", г. Львов, Украина

\section{ИННОВАЦИОННОЕ РАЗВИТИЕ ТРАНСПОРТНОЙ СИСТЕМЫ УКРАИНЫ}

Исследование составляющих транспортного комплекса позволило утверждать, что транспортная система является значительным и важным сегментом для экономики страны, стабильное функционирование которого обеспечивает необходимые условия целостности государства и повышения уровня жизни населения. Проанализировано состояние транспортной системы Украины и рассмотрены перспективы ее развития в контексте кризисных изменений. Определены негативные тенденции в перевозках. Отмечено уменьшение грузооборота железнодорожного, автомобильного, водного, трубопроводного и авиационного транспорта. Рынок транспортных услуг удовлетворяет только базовые потребности экономики Украины и населения в перевозках. Выявлено, что неразвитая система управления транспортной системой, состояние производственнотехнической базы и технологический уровень организации перевозок по многим параметрам не соответствуют растущим потребностям общества, что негативно влияет на транспортную систему страны. Перспективными для государства определены инновационные преобразования в направлении усовершенствования структуры международных транспортно-логистических систем, производства инновационных информационно-управляющих технологий, построенных на моделировании интегрированных транспортных систем, развитие мультимодальных перевозок и ускоренное интегрирование национальной транспортной системы.

Ключевые слова: инновации; транспортно-дорожный комплекс; перевозки; устойчивое развитие; инфраструктура; государственная политика.

K. P. Danylkiv, K. V. Horbova, O. Ya. Poburko Lviv Polytechnic National University, Lviv, Ukraine

\section{INNOVATIVE DEVELOPMENT OF THE TRANSPORT SYSTEM OF UKRAINE}

Transport is considered to be one of the leading branches of material production; it participates in the formation of the sectoral structure of national production, in the allocation of production capacities and the formation of prices. Through economic channels, the transport industry affects all indicators of quality of life, creating the benefits of economic growth in the region and the country, developing a national infrastructure. The quality of functioning of the transport system depends on the quality of the formation of the social environment. Greater mobility and time-saving as the most important resource of the present create wider opportunities for human development. Therefore, the purpose of the work is to analyze the innovation activity of transport enterprises, determine the role of financing in the innovative development of the industry, and propose measures to increase innovation activity. The authors have analysed the main directions and practical results of introducing innovations in the transport and road sector of Ukraine, identifies the factors that hamper innovation processes in the transport sector, substantiates the priority directions of the state policy to activate innovative transformations in the transport sector with the aim of modernizing the transport and road complex. The object of research is the transport and road complex of Ukraine. Nowadays, the innovative activity of transport enterprises is characterized by negative dynamics, namely: the number of scientific organizations, scientists, innovative-active transport enterprises. Innovative development of the industry is hampered by a lack of financing for the introduction of innovations at the enterprises of the transport and road complex and the slow pace of implementing structural reforms in the sphere of the transport and road complex. There is an objective need for a balanced state policy for the development of a transport and road complex on an innovative basis.

Keywords: innovation; road transport complex; transportation; sustainability; infrastructure; state policy. 